\title{
Fostering Student Responses in the Literature Classroom: The Implementation of Aesthetigrams as a Meaning-Making Strategy
}

\author{
Amélie Lemieux \\ McGill University, Montreal
}

\begin{abstract}
The province of Quebec has more people with low literacy than the national Canadian average, which results in a weak foundation for formal learning at the post-secondary level. Research indicates that students' loss of interest in French classes is a common cause for this alarming phenomenon. In addition to this issue, approximately half of the Quebec population over 16 years of age (52\%) have a literacy level at or above the estimated level for living efficiently [1]. This is a serious educational and social challenge that needs to be addressed in educational research.

In an effort to reduce the weak literacy rate of students, this paper suggests an alternative teaching of Quebec playwright Wajdi Mouawad's Incendies in three different secondary 5 (or grade 11) classes. Another objective of this research is to adopt appropriate methods to reinforce interest in Francophone Quebec literature and develop a further interest in reading.
\end{abstract}

\section{Introduction}

Francophone Quebec, as a minority culture in North America, needs to celebrate not only its uniqueness within the North American context, but also what it shares. Literature, as a branch of the arts, takes the pulse of the society that it represents. Apart from functioning as an effective instrument of education [2], literature is also the means through which language skills are most often taught in Quebec's French classes.

Quebec's current challenge is to alter the proportion of individuals over 16 years who are only able to deal with simple reading material involving uncomplicated tasks. As a solution, this research puts forward a method to increase interest in French Quebec literature. The issue of low reading and writing skills has to be resolved because literacy issues are a collective concern affecting the prosperity of the Canadian nation. The proposed research intervention is likely to contribute to an increased interest in reading and better literacy skills and, in turn, result in a change to the current negative statistics.

\section{Reader-response theory: An overview}

Reader-response theory was introduced by Louise Rosenblatt in her success Literature as Exploration [3], and was described further in her acclaimed book The Reader, the Text, the Poem [4]. This concept was created in response to New Criticism, which advocated for close-reading, a literary approach that focused on the text's meaning alone. In this context, students' perspectives and opinions were perceived as insignificant, and only the correct reading was the one the teacher put forward.

The goal of the close-reading pedagogy was to extract the meaning from the text, rather than drawing on one's personal experiences to decrypt it. On that matter, Robert Probst shared one of his memories of when he was a student who experienced that pedagogy: "[As students,] who we were and what we thought, felt, remembered, valued, rejected, and wondered about were more or less irrelevant. The meaning was in the text-our job was to dig it out [5]". This method of approaching and teaching literature is still implemented in Quebec classrooms today and regretfully does not foster students' understanding and perceptions of a text's meaning. By shutting out personal interpretation, it fails to provide students with efficient tools to understand a text thoroughly, i.e. by using their thoughts and opinions as referrals instead of vague indicators. As an attempted reaction to this approach, this research explores different ways students can respond to literature.

\section{Methodology}

In an effort to achieve a better understanding of students' ways of making sense of literature, 71 female participants were asked to produce written, moment-by-moment responses to a scene of the French Quebec play Incendies. Each student charted her responses in an aesthetigram, a participantgenerated map that illustrates students' moment-bymoment responses. This mapping procedure was created by Boyd White at the end of the 1990's and during the 2000's and was meant to chart and document students' opinions in response to various visual artworks $[6,7,8,9]$. 
In order to assess female responses to Incendies, this research project benefitted from the participation of students of only one gender. This enabled the research to be more focused, as it excluded the gender variable from statistical evidence.

As female high school students are often said to have more elaborate responses to literature and interest in that discipline than boys of the same age $[10,11]$, it was determined that the research was to be conducted with that population. This setting opens up a possibility for future studies, in which one could compare high school males' responses to that of females' responses generated with the current study.

\subsection{Research setting}

To address the matter of low literacy among female students, patterns of meaning-making responses were charted within aesthetigrams to provide an understanding of directions a teacher might take to increase interest in reading, specifically within classrooms of Collège Sainte-Marcelline, a private francophone high school located in Pierrefonds, on the island of Montreal. This research stresses the exploration of responses to French Quebec literature because of its relevance to today's pedagogical practices, the studies linking aesthetic education and Quebec drama being largely unexplored. For this reason, female students' reactions to Wajdi Mouawad's Incendies are investigated in this research.

As explained earlier, I focused on female subjects first in order to limit the gender variable. Another reason for choosing this population was because, as a past student in an all-girls school, I was familiar with that milieu.

The hypothesis was to receive a wide sample of positive responses to the play, which gave me a spectrum of "success patterns" on which to base future studies. A condition for that success was to build a cooperative learning atmosphere within the learning environment, to encourage student responses rather than debating which opinions were the most conclusive. As Probst notes, "the classroom must be cooperative, not combative, with students and teachers building on one another's ideas, using rather than disputing them [12]".

In light of this setting and context, another objective of this study was to foster student responses in order to raise interest in French Quebec literature. The multitude of perspectives generated by student responses had the potential to help teachers address alternate viewpoints in their respective classrooms.

\subsection{Research questions}

The paper analyses the relationships between, and frequency of, affectively- and intellectually-oriented reactions to a Quebec play and how the observed responses are related to an increased, or decreased, interest in reading. Current popular drama is the object students were asked to respond to, as the learning experiences it creates can contribute to students' engagement in their learning [13].

Throughout the study, the following research questions were investigated: How can Quebec literature be approached in an alternative and more interactive way? In particular, how do secondary school girls respond to an artwork such as a contemporary Quebec play? What patterns of responses, ranging from analytical to emotional, lead to increased or decreased interest in a particular contemporary play of Quebec literature?

\subsection{Aesthetigram-making procedure}

Aesthetigrams (Fig. 1, Tab. 1, Tab. 2) are participant-generated, autobiographical visual maps that record moment-by-moment, individual responses to aesthetic encounters one may have with artworks such as plays. The mapping procedure provides an educator/researcher with concrete data with which to study students' aesthetic responses, which otherwise remain evanescent $[14,15,16]$. A record based on student memory alone would miss considerable detail and be unreliable.

Seventy-one (71) female participants aged sixteen (16) to seventeen (17), on average, were asked to classify their aesthetic responses in an aesthetigram, which corresponded to a scene of the play. This study was conducted over a period of two weeks, at the rate of once per week during a French class.

A pre-test and a post-test were distributed to students in order to calculate whether the aesthetigram activity lead to an increased interest in French Quebec literature, determine their level of leisure reading time, and evaluate their general knowledge of French Quebec literature before and after the activity. Likert scale and open-ended questions were used for that matter. Participants completed the pre-test and drew an aesthetigram in the first session, which spanned over one (1) hour and forty-five (45) minutes. In the second session, and after an in-class discussion, they were asked to complete the post-test. This second session lasted fifty (50) minutes. The total observation time of this study was two (2) hours and thirty-five (35) minutes, which is a limitation in itself. Effectively, studies that involve students' aesthetic responses as well as aesthetigrams should be, in an ideal setting, completed within a larger time frame so the learning environment may not be restricted by time constraints.

There were a total of four phases in the completion of an aesthetigram within this research project. As a first step, all seventy-one (71) 
participants were given one (1) month to read the play Incendies in their leisure reading time. Students were asked to partake in the research project as part of an in-class activity of their mandatory high school French class. Bilingual ethics and assent forms were distributed and signed in that effect.

The second step of the research project consisted in reading a scene of the play aloud in class. Scene 37 (Letter to the Son) had been chosen prior to the activity, by joint agreement with the French teachers. I gathered that this passage would stimulate vivid reactions on the participants' part, as it deals with a complex set of emotions. Indeed, the scene recounts an emotional setting where Nawal, one of the main female characters, writes her son a letter in which she tells him that he is the prison guard who raped her when she was imprisoned in Kfar Ryat, a fictional detention centre presumable based in Lebanon, for assassinating the head of the Christian militia. While in prison, this unfortunate event left her pregnant with twins, to whom she gave birth 30 years prior to the "current" events recounted in the play.

I first asked a student at random to read this passage aloud. This procedure allowed for a first enacting of the scene, which was meant to stir all its emotional and dramatic components. Then, I asked the students to close their eyes. I read the scene so that students could hear it a second time, purposely voicing a different tone in order to allow for a wide spectrum of potential responses. In other words, reading aloud with a different rhythm and cadence can augment the possibility that students respond, if at all, to the scene. According to Larry Swartz, enacting drama allows both teachers and students to determine and identify with several identities that are developed by voice all the while "learning to develop their responses, learn about the responses of others, explore their interests and learn about the interests of others [17]".

As part of the third step, students were required to write down their moment-by-moment responses in a pre-aesthetigram form. This document was divided into four main categories: (A) emotions, (B) stylistic analysis, (C) interpretation, and (D) personal meaning. Students could list up to three elements, or moment-by-moment responses, in each of the four categories. Participants were also asked to grade the importance $(5=$ most important, $1=$ least important $)$ of each element, according to their lived aesthetic experience with the scene.

In the fourth and final step, participants were required to draw their aesthetigram with respect to the categories and elements they had listed in their pre-aesthetigram form (see Fig. 1, Tab. 1, Tab. 2). Each element was confined within a circle, whose size varied according to the importance the participant attributed to the particular elements. For example, if a student deemed a metaphor within the scene very important, then she represented that aspect by drawing it within a large scale circle (see Fig. 1). She would also add the corresponding letter within the circle, next to the said element. In other words, the letters contained in the aesthetigram illustrate the four categories explained above. In the given example (Fig. 1, Tab. 1, Tab. 2), a metaphor would correspond to the letter "B", i.e. stylistic analysis.

Students were allowed to link the elements with arrows, according to their understanding and meaning-making of scene 37 . The numeric model (i, ii, iii) was put forward in order to organize the elements within the aesthetigram. This numeric ordering did not however determine the element's importance. As explained, this was rather shown by the size of the circles.

A social sciences student drew an aesthetigram that I, in turn, illustrated below (Fig. 1). For ethical purposes, the student was given the pseudonym "Michelle".

Please note that the moment-by-moment responses, as well as her aesthetigram were originally written in French. To accommodate the journal's readership, I translated the content from French to English. As a professional translator, I ensured a faithful rendering of Michelle's voice.

\section{Analysis}

The designation of responses into specific, preestablished categories enabled teachers and myself as a researcher to track patterns of meaning-making and suggest alternative encounter emphases where this seemed advisable. For instance, when students such as Michelle demonstrated a lack of understanding by writing few or no elements of responses in a given category, the educator could suggest adopting a more thorough perspective with regard to the play's scene 37 by inciting them to look at, understand, and talk about all the categories.

One way to make students aware of their lack of elements in certain areas is to start an in-class discussion to share ideas and avenues of reflection. This particular scenario had the potential to lead to a more holistic understanding of scene 37 . In other words, in-class discussions were privileged, as they involved participants in reflecting critically on their understanding of the play's scene. The pedagogical objective of this exercise was to force students out of their comfort zone, get them to explore alternative reactions and, ultimately, help them to better reflect on their learning.

As detailed in the methodology section, pre-tests and post-tests were used to assess the participants' interest in French Quebec literature, as well as their overall interest in reading. For the purposes of this article, an example of a student's pre-test, 


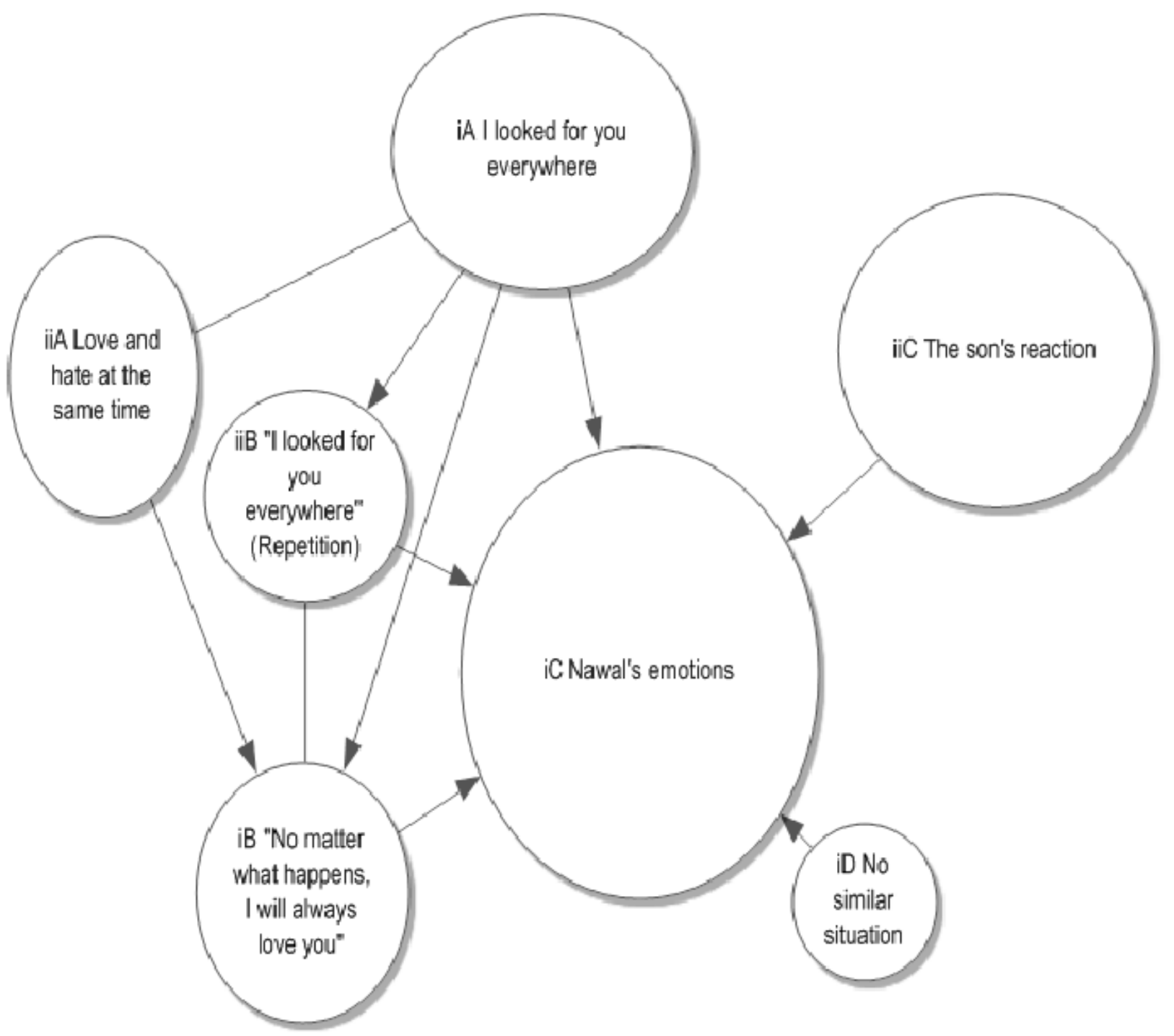

Figure 1. Aesthetigram conception: Michelle' aesthetigram in response to the play's scene 37 (Letter to the Son)

aesthetigram, and post-test are shown to illustrate the objectives of the research project.

Jade is one of the many students of one of the two social science classes who characterized her interest in French Quebec literature as "weak" in her pre-test. To further explain her statement, she mentioned that she did not enjoy reading in French, as it was not her mother tongue. Indeed, the motivation to read in a second language, especially in adolescent years, can be affected by the student's ability to understand that second language, depict language codes, and enjoy the plot overall.

Globally, Michelle preferred reading English texts and considered her interest in French Quebec literature to be insufficient at the beginning of the study. When asked to write down the name of a Quebec playwright, Michelle was unable to do so, despite the fact that all students have to study at least one Quebec play during their high school years, according to the Quebec curriculum.
Michelle also wrote that her leisure reading time was, in her opinion, more than sufficient, but that she read teen magazines in English (e.g. Seventeen Magazine) as well as newspaper articles in that language. This preference towards short, simple texts does not come as a surprise, considering the general apathy towards reading more complex texts amongst adolescents, which has been widely documented in recent research (see Brozo and Flynt). This sounds an alarm in the field of education. Indeed, "the less time students spend engaged with content area text, the more underdeveloped their reading skills will be for this type of material [18]".

Michelle's aesthetigram contained all four categories listed in Table 1: (A) emotions, (B) stylistic analysis, (C) interpretation and (D) personal meaning. This shows that the student's moment-bymoment responses were distributed in each category (Fig. 1). Despite Michelle writing that she could not identify with the scene because she had not gone 
through a similar experience (see Tab. 2, moment iD), her mapping exemplifies that she made the effort to fill in at least one element in each category. This demonstrates her capacity to reflect on her personal experiences, as well as her values and understanding of scene 37 of Incendies. Effectively, students' responses tend to converge towards values that are imbedded in their own personalities $[19,20]$.

In a section of the post-test, Michelle wrote that the most prominent categories were those of emotions, stylistic analysis, and interpretation because she felt that these best represented her thoughts. The multitude and variety of student responses provide a good starting point for discussion [21]. As responses depend on each individual, the aesthetigram-making activity can guide teachers in addressing missing categories and students in discovering their peers' differing responses. Ultimately, one of the main pedagogical objectives is to reach equilibrium between all categories in order to instill a more holistic understanding of the scene within each learner.

Michelle's post-test comments were encouraging. Firstly, she evaluated her interest in French Quebec literature as 'moderate'. This assessment shows that her interest increased by one (1) level following the aesthetigram activity, going from weak to moderate.

Table 1. Aesthetigram categories

\begin{tabular}{|l|l|}
\hline \multicolumn{2}{|c|}{ Aesthetigram categories } \\
\hline A & Emotions \\
\hline B & Stylistic Analysis \\
\hline C & Interpretation \\
\hline D & Personal Meaning \\
\hline
\end{tabular}

She also noted that, in the context of her French literature class, the mapping exercise lead to her being more motivated to read French Quebec novels and plays. Moreover, she sensed that, after the aesthetigram activity, she was more knowledgeable about French Quebec drama than prior to completing the aesthetigram activity. This was not an isolated case and was observed in other students who participated in the research project. This change can inform teachers and researchers of the positive effects of aesthetigram-making on students' learning methods in the literature classroom.

As part of her post-test observations, Michelle added that she enjoyed constructing an aesthetigram because it allowed her to better understand, appreciate, and interpret several elements of the chosen scene. She formulated her satisfaction as such: "after making my aesthetigram, I was able to better understand the scene we read in class". This assertion ties in well with Vine Jr. and Faust's assertion on personal interactions with the text that create valuable meaning-making ways of understanding literature: "[when using readerresponse strategies in our classrooms], we need to have [...] faith that our students will profit as much from their own meaning-making as they might have from ours [22]". This pedagogical approach can empower students in believing that their opinion is worthy of being discussed and, in the context of a discussion, can help others learn and understand a literary text.

Table 2. Description of the moments experienced by Michelle, a social sciences student

\begin{tabular}{|c|l|}
\hline & Responses / Elements \\
\hline iA & $\begin{array}{c}\text { When Nawal explains that she looked for him everywhere, I was shocked because I could not } \\
\text { imagine how she felt (importnance: 3). }\end{array}$ \\
\hline iiA & $\begin{array}{c}\text { How could Nawal love him and hate him at the same time? I did not like that, mainly because } \\
\text { it's not fair that she went through that event (importance: } 2 \text { ). }\end{array}$ \\
\hline iB & Repetion of "no matter what happens, I will always love you" (importance: 2 ). \\
\hline iiB & Repetion of "I looked for you" (importance: 2). \\
\hline iC & $\begin{array}{l}\text { In terms of her emotional side, she seems very weak in my eyes, but she knows that she has } \\
\text { to tell him (importance: 4). }\end{array}$ \\
\hline iiC & $\begin{array}{c}\text { The son's reaction seems emotionless (importance: 3). } \\
\text { iD }\end{array}$ \\
\hline
\end{tabular}

As part of her post-test observations, Michelle added that she enjoyed constructing an aesthetigram because it allowed her to better understand, appreciate, and interpret several elements of the chosen scene. She formulated her satisfaction as such: "after making my aesthetigram, I was able to better understand the scene we read in class". This assertion ties in well with Vine Jr. and Faust's assertion on personal interactions with the text that create valuable meaning-making ways of understanding literature: "[when using readerresponse strategies in our classrooms], we need to have [...] faith that our students will profit as much from their own meaning-making as they might have 
from ours [22]". This pedagogical approach can empower students in believing that their opinion is worthy of being discussed and, in the context of a discussion, can help others learn and understand a literary text.

Michelle even considered using aesthetigrams in other learning contexts, such as her English literature class. She explained: "Aesthetigrams could help students who have a hard time understanding English novels". Her opinion on that matter implies that aesthetigram-making is transferable to other genres and disciplines. This application would be feasible, thanks to the "essential similarity of the meaningmaking process across literary genres [23]". Further research concerning aesthetigram applications in English literature would be advisable in that context.

Michelle's overall experience with aesthetigrammaking has proven to be effective in terms of increasing interest in French Quebec literature, particularly when reading French Quebec plays within the context of her French literature class.

As a follow-up activity, in-class discussions are suggested in order to foster student exchanges and broaden perspectives on the scene. As Carole Cox and Paul S. Boyd-Batstone suggest, "[C]onnecting the text to life takes place in dialogue with others about the multilayered meanings of the story, the public and personal understandings of the text [24]". In this way, students can first accept or reject the experiences of others in relation to their own, and thus create meaning-making strategies to better understand a text. Later on, they can even reflect on the discussions, thus benefitting from the elements that were discussed in class. This flexibility notably allows for a more thorough teaching and learning of literature.

\section{Conclusion}

My work with senior high-school students of varying ethnic backgrounds reflects the Quebec multicultural reality. Students were encouraged to listen to, cope with, experience and, importantly, acknowledge the aesthetic responses of their peers during in-class discussions. My research project is of importance to education because "motivating students to engage in reading by teaching them with the use of new strategies is a crucial factor in raising literacy levels [25]". The results show that the interest in Quebec drama generally increased among the participants. Their prose literacy skills, or those needed to use information from textual narratives, increased as well. This is of utmost importance given that young adults need a high literacy levels to function well in society. The innovative use of aesthetigrams provided educators with a means to understand students' aesthetic, emotional and intellectual responses to Quebec literature in an effort to develop a deeper interest in, and retune
Quebec's consciousness of, its culture one student at a time.

\section{Acknowledgements}

The author is grateful to Dr. Boyd White for his thoughtful suggestions, encouragements, and feedback, McGill's Faculty of Education and the Social Sciences and Humanities Research Council of Canada for their financial support throughout this research. She would also like to thank Collège Sainte-Marcelline for allowing her to conduct this research with their students.

\section{References}

[1] J. O’Sullivan, P. Canning, L. Siegel, and M. Olivieri, Key Factors to Support Literacy Success in School-aged Populations, Canadian Education Statistics Council, Toronto, Canada, 2009.

[2] Carroll, N., "The Wheel of Virtue: Art, Literature, and Moral Knowledge", The Journal of Aesthetics and Art Criticism, Temple University, Philadelphia, Pennsylvania, 2002, 60 (1), pp. 3-26.

[3] Rosenblatt, L. M., Literature as Exploration, Noble \& Noble, New York, New York, 1938/1976.

[4] Rosenblatt, L. M., The Reader, the Text, the Poem: The Transactional Theory of the Literary Work. Carbondale and Edwardsville, IL: Southern Illinois University Press.

[5] Probst, R. E., Response \& Analysis: Teaching Literature in Secondary School (2nd ed.), Heinemann, Portsmouth, New Hampshire, 2004.

[6] White, B. "Aesthetigrams: Mapping Aesthetic Experiences". Studies in Art Education, 1998, 39 (40), pp. 321-335.

[7] B. White and S. Tompkins (2005). "Doing Aesthetics to Facilitate Meaning-Making". Arts \& Learning Research Journal, Brown University, Providence, Rhode Island, American Educational Research Association, 2005, 21 (1), pp. 1-36.

[8] White, B. “Aesthetic Encounters: Contributions to Teacher Education". International Journal of Education \& the Arts, 2007, 8 (17), pp. 1-28.

[9] White, B. "Private Perceptions, Public Reflections Aesthetic Encounters as Vehicles for Shared Meaning- Making". International Journal of Education \& the Arts, 2011, 12 (LAI 2), pp. 1-26.

[10] Brozo, W. G., To Be a Boy, to Be a Reader: Engaging Teen and Preteen Boys in Active Literacy, 
The International Reading Association, Newark, Delaware, 2002.

[11] Royer, É., Leçons d’Éléphants: Pour la Réussite des Garçons à l'École, École et Comportement, Quebec City, Quebec, 2010.

[12] Probst, R. E., Response \& Analysis: Teaching Literature in Secondary School (2nd ed.), Heinemann, Portsmouth, New Hampshire, 2004.

[13] R. Upitis, and K. Smithrim, Learning through the Arts: National Assessment Final Report, The Royal Conservatory of Music, Toronto, Canada, 2003.

[14] B. White and S. Tompkins (2005). "Doing Aesthetics to Facilitate Meaning-Making". Arts \& Learning Research Journal, Brown University, Providence, Rhode Island, American Educational Research Association, 2005, 21 (1), pp. 1-36.

[15] White, B. "Aesthetic Encounters: Contributions to Teacher Education". International Journal of Education \& the Arts, 2007, 8 (17), pp. 1-28.

[16] White, B. "Private Perceptions, Public Reflections Aesthetic Encounters as Vehicles for Shared Meaning- Making". International Journal of Education \& the Arts, 2011, 12 (LAI 2), pp. 1-26.

[17] Swartz, L. "Theatre for Younger People: Does it Matter?" In K. Gallagher, and D. Booth (Eds.), How Theatre Educates: Convergences \& Counterpoints, 2003, Toronto, Ontario, University of Toronto Press, pp. 198-206.

[18] W. G. Brozo and E. Sutton Flynt, "Motivating Students to Read in the Content Classroom: Six Evidence-Based Principles". The Reading Teacher, 2008, 62 (2), pp. 172-174.

[19] White, B. "Aesthetic Encounters: Contributions to Teacher Education". International Journal of Education \& the Arts, 2007, 8 (17), pp. 1-28.

[20] White, B. "Private Perceptions, Public Reflections Aesthetic Encounters as Vehicles for Shared Meaning- Making”. International Journal of Education \& the Arts, 2011, 12 (LAI 2), pp. 1-26.

[21] Probst, R. E., Response \& Analysis: Teaching Literature in Secondary School (2nd ed.), Heinemann, Portsmouth, New Hampshire, 2004.

[22] Vine Jr., H. A., and M. A. Faust, Situating Readers: Students Making Meaning of Literature, National Council of Teachers of English, Urbana, Illinois, 1993.
[23] Vine Jr., H. A., and M. A. Faust, Situating Readers: Students Making Meaning of Literature, National Council of Teachers of English, Urbana, Illinois, 1993.

[24] Cox, Carole, and P. S. Boyd-Batstone, Engaging English Learners: Exploring Literature, Developing Literacy, and Differentiating Instruction, Allyn \& Bacon (Pearson), Boston, Maryland, 2009.

[25] J. O’Sullivan, P. Canning, L. Siegel, and M. Olivieri, Key Factors to Support Literacy Success in School-aged Populations, Canadian Education Statistics Council, Toronto, Canada, 2009. 